\section{ANALISIS PERBANDINGAN KINERJA VALUE AT RISK BERBASIS ARCH, GARCH, DAN EGARCH SEBELUM, SAAT, DAN SETELAH KRISIS GLOBAL TAHUN 2008 PADA JKSE, KLSE, STI, PSEI, HIS, KOSPI, SSE DAN N225}

JURNAL

MANAJEMEN

INDONESIA

Vol. 12 - No. 4 April 2013
Riko Hendrawan ${ }^{1} \&$ Pebri Yanida ${ }^{2}$

\section{ABSTRAK}

Relatif tidak stabilnya kondisi ekonomi global dikarenakan krisis global tahun 2008 membuat para investor cenderung lebih berhati-hati dalam memilih sektor saham untuk dapat menghindari risiko yang terjadi. Untuk dapat meminimalkan terjadinya risiko tersebut, investor dapat melakukan pengukuran risiko, salah satunya adalah dengan metode Value at Risk (VaR). Investor dapat menggunakan nilai VaR sebagai salah satu tolak ukur untuk dapat menetapkan seberapa besar target risiko di masa yang akan datang. Perhitungan VaR dalam penelitian ini berbasis model ARCH, GARCH, dan EGARCH, tujuannya untuk membandingkan kinerja ketiga model tersebut untuk memilih model mana yang paling efektif diterapkan pada kondisi pasar normal maupun saat krisis. Untuk menguji validitas dari model VaR ini, dilakukan sebuah uji yang dinamakan uji backtesting dengan menggunakan metode Kupiec dengan cara membandingkan actual return dengan VaR harian. Penelitian ini bertujuan untuk mengetahui tingkat efektifitas Model Valeu at Risk dengan Metode Kupiec pada JKSE, KLSE, PSEi, HSI, KOSPI, SSE dan N255. Jenis penelitian yang digunakan pada penelitian ini adalah deskriptif komparatif. Pengambilan sampel penelitian dilakukan dengan metode nonprobability sampling jenis purposive sampling. Hasil penelitian ini menyatakan pengujian Value at Risk dengan tingkat kepercayaan 99\% dan 95\% untuk periode tahun 2005 sampai dengan tahun 2012 tidak dapat diterima (ditolak) untuk seluruh indeks saham yang diteliti, menggunakan model ARCH dan GARCH dan dapat diterima sebagian untuk model EGARCH.

Kata kunci: Value at Risk, Kriteria Kupiec, ARCH, GARCH, EGARCH, backtesting

\section{PENDAHULUAN}

Dari sekian banyak metode pengukuran risiko yang ada, VaR yang paling banyak digunakan dalam pengukuran risiko karena metode ini menggabungkan keunggulan dari pengukuranpengukuran risiko sebelumnya. Penerapan metode VaR ini merupakan salah satu bagian dari manajemen risiko. Investor dapat menggunakan nilai VaR sebagai salah satu tolak ukur untuk dapat menetapkan seberapa besar target risiko di masa yang akan datang.

VaR ini sendiri dapat diartikan sebagai estimasi kerugian maksimum yang akan didapat selama periode waktu (time period) tertentu dalam kondisi pasar normal pada tingkat kepercayaan (confidence level) tertentu. Secara sederhana sebenarnya VaR ingin menjawab pertanyaan "seberapa besar (dalam persen atau sejumlah uang tertentu) investor dapat merugi selama waktu investasi t dengan tingkat kepercayaan (1- $\alpha)^{\prime \prime}$ Menurut Jorion (2007:108) Value at Risk merupakan pengukuran kerugian harapan terburuk dalam kondisi pasar yang normal pada kurun waktu T dengan tingkat kepercayaan tertentu $\alpha$.

Dosen Tetap Prodi MM Universitas Telkom Universitas Telkom 
Dalam perhitungan $\mathrm{VaR}$, hal terpenting yang harus dilakukan adalah menentukan jenis metodologi dan asumsi yang sesuai dengan distribusi return sekuritas. Hal ini dikarenakan

JURNAL MANAJEMEN INDONESIA

Vol. 12 - No. 4 April 2013 perhitungan VaR didasarkan pada distribusi return sekuritas. Ada beberapa penerapan metode utama yang dapat dilakukan dalam menghitung nilai VaR, diantaranya dengan menggunakan metode parametrik (atau disebut juga metode varian-kovarian), metode Simulasi Monte Carlo dan Simulasi Historis. Ketiga metode mempunyai kelebihan dan kekurangannya masing-masing. Pertama, metode Parametrik mengasumsikan bahwa return berdistribusi normal dan return portofolio bersifat linier terhadap return aset tunggalnya. Kedua faktor ini menyebabkan estimasi yang lebih rendah terhadap potensi volatilitas aset atau portofolio di masa depan. Kedua, metode Simulasi Monte Carlo mengasumsikan bahwa return berdistribusi normal yang disimulasikan dengan menggunakan parameter yang sesuai dan tidak mengasumsikan bahwa return portofolio bersifat linier terhadap return aset tunggalnya. Ketiga, VaR dengan menggunakan metode Simulasi Historis adalah metode yang mengesampingkan asumsi return yang berdistribusi normal maupun sifat linier antara return portofolio terhadap return aset tunggalnya.Menurut Cabedo \& Moya (2003) Metode Simulasi Historis merupakan metode yang merepresentasikan cara paling sederhana dalam mengestimasi Value at Risk dalam berbagai portofolio. Metode simulasi historis ini juga dikenal sebagai unconditional empirical method, metode ini menghasilkan jumlah yang tepat dari pengecualian dari waktu ke waktu tetapi pengecualian cenderung berkumpul bersama-sama selama periode krisis. Hal ini menyebabkan metode ini gagal digunakan pada saat-saat krisis dikarenakan metode ini hanya fokus pada jumlah pengecualian tanpa mempertimbangkan pengecualian pemilihan waktu (Sheedy, 2008). Sehingga untuk menyempurnakan metode ini dicampurkan teknik parametrik seperti ARCH/GARCH untuk mengatasi kelemahan pada metode simulasi historis ini, terutama ketidakmampuannya dalam meramalkan volatilitas terbaru dari pasar. Metode tersebut dikenal dengan nama filtered historical simulation (Barone-Adesi dan Giannopoulos, 1998).

Untuk data keuangan dan saham dengan tingkat fluktuasi tinggi, model auto-korelasi dengan varians tidak konstan adalah model yang lebih realistis dibandingkan dengan model auto-korelasi dengan varians konstan, sehingga model $\mathrm{ARCH}$ yang lebih realistis untuk memodelkan volatilitas data saham. Model Autoregressive Conditional Heteroskedastic (ARCH) yang diperkenalkan oleh Engle (1982) digunakan untuk memprediksi risiko saham harian. Model tersebut mampu meramalkan ragam bersyarat melalui data sisaan pada model rataan. Model rataan adalah model untuk menduga nilai pengembalian harga saham, contohnhya seperti model ARIMA atau model regresi standar (Enders, 1995). Model ARCH dalam penerapannya memiliki kelemahan yaitu ketika diperoleh ordo besar yang menyebabkan presisi dari estimator menjadi berkurang. Bollerslev (1986) mengembangkan sebuah model yang dikenal sebagai Generalized Autoregressive Conditional Heteroskedasticity (GARCH) atau disebut juga conditional empirical method merupakan pengembangan dari model ARCH dan merupakan model yang lebih efisien daripada $\mathrm{ARCH}$. Metode ini menyediakan hasil keseluruhan terbaik dengan mempertimbangkan baik jumlah pengecualian dan juga pengecualian waktu. Model GARCH mampu memodelkan volatility clustering pada data deret waktu dengan baik dan banyak diaplikasikan pada berbagai bidang, khususnya ekonomi keuangan. Conditional empirical VAR tidak dapat ditolak karena mampu menangani multi-day risk horizon sebaik menangani single-day risk horizon (meskipun dengan kecenderungan untuk menjadi terlalu konservatif) dan selanjutnya, model tidak dapat ditolak ketika dites selama periode krusial turbulensi pada 2007-2008 secara terpisah (Sheedy, 2008).

Model GARCH menangkap gagasan bahwa pergerakan harga lebih lanjut yang besar cenderung mengikuti guncangan harga awal. Maka dari itu disebut klusterisasi volatilitas dapat dijelaskan oleh perilaku pelaku pasar dalam menanggapi guncangan harga awal. Likuiditas pasar berkurang sehingga dampak pasar perdagangan diperburuk dan kita amati pergerakan 
harga lebih lanjut yang besar (volatilitas meningkat) setelah shock awal. Model GARCH berbasis risiko ini berpotensi mencerminkan karakteristik pasar dan beradaptasi dengan perubahan kondisi pasar setelah market shock (Sheedy, 2009). Model ARCH/GARCH mengasumsikan volatilitas dari sisaan bersifat simetris, yaitu pengaruh shock terhadap volatilitas sama besar ketika terjadi shock positif ataupun negatif. Namun dalam pasar uang dan pasar modal, sering ditemukan bahwa volatilitas dari error ketika ada guncangan negatif lebih besar daripada ketika ada guncangan positif. Kasus ini disebut sebagai guncangan asimetris (asymmetric shock), dimana penurunan tajam (efek negatif) tidak serta merta akan diikuti dengan kenaikan (efek positif) dalam ukuran yang sama pada periode berikutnya. Untuk mengatasi persoalan guncangan asimetris ini, model yang biasa digunakan adalah model EGARCH (Exponential GARCH) yang dikembangkan oleh Nelson pada tahun 1991. Oleh karena itu, pada penelitian ini penulis akan menghitung nilai VaR dengan menggunakan ketiga model perhitungan volatilitas $A R C H, G A R C H$, dan EGARCH untuk membandingkan kinerja ketiga model tersebut dan memilih model mana yang paling efektif diterapkan pada kondisi pasar normal maupun saat krisis.

Selanjutnya, untuk menguji validitas dari VaR ini, kita harus melakukan sebuah uji yang dinamakan uji backtesting. Backtesting adalah suatu kerangka kerja statistik formal yang terdiri dari verifikasi bahwa kerugian sebenarnya sejalan dengan proyeksi kerugian. Kajian backtesting digunakan untuk menentukan apakah model risiko dapat berfungsi secara efektif di pasar bergejolak maupun pasar yang tenang, dan jika demikian, model risiko mana yang tampil terbaik. Untuk memverifikasi keakuratan dari model ini adalah dengan merekam tingkat kegagalan yang memberikan proporsi kali VaR terlampaui dalam sampel yang diberikan dengan menggunakan Metode Kupiec. Keunggulan dari Metode Kupiec ini adalah kita dapat mengetahui akurasi model VaR dalam memproyeksi potensi kerugiannya dengan cara membandingkan actual return dengan VaR harian. Apabila proporsi kesalahan model VaR tidak sesuai dengan tabel Kriteria Kupiec maka model dianggap tidak valid (Kupiec:1995).

Pada tulisan ini akan dibahas perhitungan VaR pada Jakarta Composite Index (JKSE), Kuala Lumpur Composite Index (KLSE), Straits Times Index (STI), Philippines Stock Exchange index (PSEi), Hang Seng Index (HSI), Korea Composite Stock Price Index (KOSPI), Shanghai Stock Exchange (SSE), dan Nikkei 225 (N225) dengan menggunakan Model ARCH, GARCH, dan EGARCH.

\section{PEMBAHASAN}

VaR dapat didefinisikan sebagai estimasi kerugian maksimum yang akan didapat selama periode waktu (time period) tertentu dalam kondisi pasar normal pada tingkat kepercayaan (confidence interval) tertentu. Secara sederhana VaR ingin menjawab pertanyaan "seberapa besar (dalam persen atau sejumlah uang tertentu) investor dapat merugi selama waktu investasi t dengan tingkat kepercayaan (1- $\boldsymbol{\alpha})$ ". Berdasarkan pertanyaan di atas, dapat dilihat adanya tiga variabel penting dalam menghitung nilai VaR, yaitu besar kerugian, periode waktu dan besarnya tingkat kepercayaan.

Perhitungan model VaR dapat dilakukan dengan menggunakan rumus pada persaman (1) :

VaR Vo* $\sigma^{*} \alpha^{*} \mathrm{Vt}$
JURNAL

MANAJEMEN

INDONESIA

Vol. 12 - No. 4

April 2013
Dimana :
$\begin{aligned} \text { Vo } & =\text { Faktor Pasar } \\ \sigma & =\text { Volatilitas saham } \\ \alpha & =\text { Tingkat kepercayaan } \\ t & =\text { Waktu }\end{aligned}$ 
Dalam tesis ini, perhitungan VaR menggunakan pemodelan $\mathrm{ARCH}, \mathrm{GARCH}$ dan EGARCH

JURNAL MANAJEMEN INDONESIA

Vol. 12 - No. 4 April 2013 untuk menghitung nilai volatilitas saham harian $(\sigma)$ dari seluruh objek penelitian. Dari hasil perhitungan didapat untuk indeks JKSE, KLSE, STI, SSE, PSEI NIKKEI, HANGSENG, diperoleh model terbaik yaitu $\operatorname{ARCH}(2), \operatorname{GARCH}(1,1)$ dan $\operatorname{EGARCH}(1,1)$ karena ketiga model tersebut memiliki probabilitas $<0,05$ dan nilai AIC dan SIC terkecil daripada model usulan lainnya. Sedangkan untuk indeks KOSPI diperoleh model terbaik $\operatorname{ARCH}(1), \operatorname{GARCH}(1,1)$, dan $\operatorname{EGARCH}(1,1)$. Selanjutnya model-model terbaik yang telah dipilih digunakan untuk melakukan peramalan volatilitas.

Faktor pasar (VO) yang diperlukan dalam penelitian ini adalah harga saham (penutupan) pada tanggal 3 Januari 2005 sampai 31 Desember 2012 untuk 8 indeks saham di Asia, yaitu JKSE, KLSE, STI, SSE, PSEI, HANGSENG, N225, dan KOSPI. Periode waktu penelitian ini kurang lebih 8 (delapan) tahun dimulai dari tanggal 3 Januari 2005 sampai dengan 31 Desember 2012. Pada penulisan tesis ini digunakan tingkat kepercayaan $(\alpha)$ sebesar $99 \%$ (sembilan puluh sembilan persen) dan 95\% (sembilan puluh lima persen). Dengan tingkat kepercayaan 99\% tersebut berarti risiko terjadinya kesalahan dari hasil penelitian ini dibatasi hanya sebesar $1 \%$ (satu) persen dan tingkat kepercayaan 95\% tersebut berarti risiko terjadinya kesalahan dari hasil penelitian ini dibatasi hanya sebesar $5 \%$ (lima) persen. Dengan diketahuinya variabel $\alpha$ dan $\sigma$ maka dapat dihitung nilai VaR. Langkah-langkah perhitungan VaR untuk saham JKSE adalah sebagai berikut :

a) Andaikan harga penutupan saham harian pada tanggal 5 Januari 2005 adalah Rp 1000,-

b) Dan standar Deviasi dari return saham JKSE pada hari tersebut adalah 1,67\%

c) Time horizon sesuai aturan BASEL II adalah 10 hari trading. Sehingga standar deviasi nantinya harus dikalikan dengan

$$
\sqrt{\frac{(10)}{252}}
$$

d) Confident level $99 \%(Z \alpha=2,58)$

a. Maka perhitungan VaR saham JKSE adalah :

$$
\text { b. } \begin{aligned}
\operatorname{Var}(99 \%) & =1000 \times \alpha \times \sigma \times \sqrt{\frac{(10)}{252}} \\
1 . & =1000 \times 2.58 \times 1,67 \% \times \sqrt{\frac{(10)}{252}} \\
2 . & =8,58
\end{aligned}
$$

Sehingga VaR dari saham JKSE dalam rentang waktu 10 hari trading dengan confidence level 99\% adalah 8,58.

Hasil perhitungan di atas menyatakan bahwa potensi kerugian maksimum sebesar Rp. 8,58 apabila kit a berinvestasi sebesar Rp. 1000 pada saham JKSE selama 10 hari perdagangan. Setelah didapat nilai VaR maka selanjutnya kita dapat melakukan uji backtesting. Untuk melakukan pengujian terhadap model-model VaR dilakukan dengan langkah-langkah sebagai berikut :

1. Menghitung nilai VaR harian untuk prediksi 1 (satu) tahun (mulai Januari 2005 sampai dengan Desember 2005), perhitungan VaR ini dihitung dengan menggunakan tingkat kepercayaan $99 \%$.

2. Menghitung actual return melalui profit/loss harian sepanjang 1 (satu) tahun tersebut;

3. Membandingkan actual return dengan VaR harian, apabila actual return lebih besar dari VaR, maka hitung sebagai failure. 
4. Menghitung jumlah failure dan mencocokkan jumlah tersebut dengan Tabel Kupiec untuk melakukan backtesting tersebut;

5. Mengulang langkah 1 sampai 4 untuk menguji model VaR pada tahun-tahun berikutnya (2006-2012).

a. Tahun 2005

\begin{tabular}{|l|l|l|l|l|l|}
\hline \multirow{2}{*}{$\begin{array}{l}\text { Backtesting VaR } \\
\text { dengan ARCH }\end{array}$} & \multicolumn{2}{|l|}{$\begin{array}{l}\text { Total } \\
\text { Failure }\end{array}$} & \multicolumn{2}{l|}{ Kriteria Kupiec } & \multirow{2}{*}{ Hasil } \\
\cline { 2 - 5 } & $99 \%$ & $95 \%$ & $99 \%$ & $95 \%$ & \\
\hline JKSE & 136 & 145 & $\mathrm{~N}<7$ & $6<\mathrm{N}<20$ & DITOLAK \\
\hline KLSE & 147 & 157 & $\mathrm{~N}<7$ & $6<\mathrm{N}<20$ & DITOLAK \\
\hline STI & 123 & 143 & $\mathrm{~N}<7$ & $6<\mathrm{N}<20$ & DITOLAK \\
\hline SSE & 180 & 190 & $\mathrm{~N}<7$ & $6<\mathrm{N}<20$ & DITOLAK \\
\hline PSEI & 162 & 168 & $\mathrm{~N}<7$ & $6<\mathrm{N}<20$ & DITOLAK \\
\hline HANGSENG & 153 & 163 & $\mathrm{~N}<7$ & $6<\mathrm{N}<20$ & DITOLAK \\
\hline NIKKEI & 119 & 135 & $\mathrm{~N}<7$ & $6<\mathrm{N}<20$ & DITOLAK \\
\hline KOSPI & 120 & 128 & $\mathrm{~N}<7$ & $6<\mathrm{N}<20$ & DITOLAK \\
\hline
\end{tabular}

Dari Tabel 1 terlihat bahwa untuk model VaR dengan tingkat kepercayaan 99\%, hipotesis 1 ditolak untuk semua indeks saham, hal ini dikarenakan Total Failure melebihi jumlah yang persyaratan Kupiec Criteria. Dikarenakan pada pemodelan VaR menggunakan tingkat kepercayaan 99\% semua indeks saham tidak memenuhi kriteria Kupiec, maka dilakukan lagi pemodelan baru dengan menggunakan tingkat kepercayaan sebesar 95\%. Hal ini dilakukan untuk mengetahui apakah dengan tingkat kepercayaan yang lebih rendah model VaR ini dapat diterima atau tidak. Seperti yang terlihat dari Tabel 1 di atas, untuk model VaR (95\%), hipotesis 2 juga ditolak untuk semua indeks saham.

\begin{tabular}{|l|l|l|l|l|l|}
\hline \multirow{2}{*}{$\begin{array}{l}\text { Backtesting VaR } \\
\text { dengan GARCH }\end{array}$} & \multicolumn{2}{|l|}{$\begin{array}{l}\text { Total } \\
\text { Failure }\end{array}$} & \multirow{2}{*}{ Kriteria Kupiec } & \multirow{2}{*}{ Hasil } \\
\cline { 2 - 5 } & $99 \%$ & $95 \%$ & $99 \%$ & $95 \%$ & \\
\hline JKSE & 140 & 148 & $\mathrm{~N}<7$ & $6<\mathrm{N}<20$ & DITOLAK \\
\hline KLSE & 139 & 147 & $\mathrm{~N}<7$ & $6<\mathrm{N}<20$ & DITOLAK \\
\hline STI & 140 & 155 & $\mathrm{~N}<7$ & $6<\mathrm{N}<20$ & DITOLAK \\
\hline SSE & 181 & 191 & $\mathrm{~N}<7$ & $6<\mathrm{N}<20$ & DITOLAK \\
\hline PSEI & 162 & 168 & $\mathrm{~N}<7$ & $6<\mathrm{N}<20$ & DITOLAK \\
\hline HANGSENG & 165 & 172 & $\mathrm{~N}<7$ & $6<\mathrm{N}<20$ & DITOLAK \\
\hline NIKKEI & 134 & 142 & $\mathrm{~N}<7$ & $6<\mathrm{N}<20$ & DITOLAK \\
\hline KOSPI & 128 & 136 & $\mathrm{~N}<7$ & $6<\mathrm{N}<20$ & DITOLAK \\
\hline
\end{tabular}

Dari Tabel 2 terlihat bahwa untuk model VaR dengan tingkat kepercayaan 99\%, hipotesis 1 ditolak untuk semua indeks saham, hal ini dikarenakan Total Failure melebihi jumlah yang persyaratan Kupiec Criteria. Dikarenakan pada pemodelan VaR menggunakan tingkat kepercayaan 99\% semua indeks saham tidak memenuhi kriteria Kupiec, maka dilakukan lagi pemodelan baru dengan menggunakan tingkat kepercayaan sebesar 95\%. Hal ini dilakukan untuk mengetahui apakah dengan tingkat kepercayaan yang lebih rendah model VaR ini dapat diterima atau tidak. Seperti yang terlihat dari Tabel 2 di atas, untuk model VaR (95\%), hipotesis 2 juga ditolak untuk semua indeks saham.
JURNAL

MANAJEMEN

INDONESIA

Vol. 12 - No. 4

April 2013

Tabel 1.

Pengujian VaR dengan pemodelan volatilitas $\mathrm{ARCH}$

Tabel 2.

Pengujian VaR dengan pemodelan volatilitas GARCH

\section{5}


JURNAL

MANAJEMEN

INDONESIA

Vol. 12 - No. 4

April 2013

Tabel 3

Pengujian VaR dengan pemodelan volatilitas

EGARCH

\begin{tabular}{|c|c|c|c|c|c|}
\hline \multirow{2}{*}{$\begin{array}{l}\text { Backtesting VaR } \\
\text { dengan } \\
\text { EGARCH }\end{array}$} & \multicolumn{2}{|c|}{$\begin{array}{l}\text { Total } \\
\text { Failure }\end{array}$} & \multicolumn{2}{|c|}{ Kriteria Kupiec } & \multirow[t]{2}{*}{ Hasil } \\
\hline & $99 \%$ & $95 \%$ & $99 \%$ & $95 \%$ & \\
\hline JKSE & 51 & 66 & $\mathrm{~N}<7$ & $6<\mathrm{N}<20$ & DITOLAK \\
\hline KLSE & 0 & - & $\mathrm{N}<7$ & - & DITERIMA \\
\hline STI & 0 & - & $\mathrm{N}<7$ & - & DITERIMA \\
\hline SSE & 0 & - & $\mathrm{N}<7$ & - & DITERIMA \\
\hline PSEI & 0 & - & $\mathrm{N}<7$ & - & DITERIMA \\
\hline HANGSENG & 1 & - & $\mathrm{N}<7$ & - & DITERIMA \\
\hline NIKKEI & 0 & - & $\mathrm{N}<7$ & - & DITERIMA \\
\hline KOSPI & 0 & - & $\mathrm{N}<7$ & - & DITERIMA \\
\hline
\end{tabular}

Dari Tabel 3 terlihat bahwa untuk model VaR dengan tingkat kepercayaan 99\%, hipotesis 1 diterima untuk semua indeks saham, kecuali untuk indeks saham JKSE hal ini dikarenakan Total Failure melebihi jumlah yang persyaratan Kupiec Criteria. Dikarenakan pada indeks saham JKSE hipotesis 1 ditolak, maka dilakukan lagi pemodelan baru dengan menggunakan tingkat kepercayaan sebesar 95\%. Hal ini dilakukan untuk mengetahui apakah dengan tingkat kepercayaan yang lebih rendah model VaR ini dapat diterima atau tidak. Seperti yang terlihat dari Tabel 3 di atas, untuk model VaR (95\%), hipotesis 2 juga ditolak untuk indeks saham JKSE. Pemodelan baru dengan tingkat kepercayaan 95\% hanya dilalukan pada indeks saham JKSE karena pada pengujian dengan tingkat kepercayaan 99\%, hipotesis 1 ditolak. Sedangkan untuk ketujuh saham lainnya hipotesis 1 diterima jadi tidak diperlukan lagi pemodelan baru dengan tingkat kepercayaan $95 \%$.

\section{b. Tahun 2006}

\begin{tabular}{|l|l|l|l|l|l|}
\hline \multirow{2}{*}{$\begin{array}{l}\text { Backtesting VaR } \\
\text { dengan ARCH }\end{array}$} & \multicolumn{2}{|l|}{$\begin{array}{l}\text { Total } \\
\text { Failure }\end{array}$} & \multicolumn{2}{l}{ Kriteria Kupiec } & \multirow{2}{*}{ Hasil } \\
\cline { 2 - 5 } & $99 \%$ & $95 \%$ & $99 \%$ & $95 \%$ & \\
\hline JKSE & 115 & 124 & $\mathrm{~N}<7$ & $6<\mathrm{N}<20$ & DITOLAK \\
\hline KLSE & 89 & 97 & $\mathrm{~N}<7$ & $6<\mathrm{N}<20$ & DITOLAK \\
\hline STI & 114 & 123 & $\mathrm{~N}<7$ & $6<\mathrm{N}<20$ & DITOLAK \\
\hline SSE & 101 & 114 & $\mathrm{~N}<7$ & $6<\mathrm{N}<20$ & DITOLAK \\
\hline PSEI & 134 & 143 & $\mathrm{~N}<7$ & $6<\mathrm{N}<20$ & DITOLAK \\
\hline HANGSENG & 132 & 143 & $\mathrm{~N}<7$ & $6<\mathrm{N}<20$ & DITOLAK \\
\hline NIKKEI & 172 & 178 & $\mathrm{~N}<7$ & $6<\mathrm{N}<20$ & DITOLAK \\
\hline KOSPI & 159 & 168 & $\mathrm{~N}<7$ & $6<\mathrm{N}<20$ & DITOLAK \\
\hline
\end{tabular}

Dari Tabel 4 terlihat bahwa untuk model VaR dengan tingkat kepercayaan 99\%, hipotesis 1 ditolak untuk semua indeks saham, hal ini dikarenakan Total Failure melebihi jumlah yang persyaratan Kupiec Criteria. Dikarenakan pada pemodelan VaR menggunakan tingkat kepercayaan 99\% semua indeks saham tidak memenuhi kriteria Kupiec, maka dilakukan lagi pemodelan baru dengan menggunakan tingkat kepercayaan sebesar 95\%. Hal ini dilakukan untuk mengetahui apakah dengan tingkat kepercayaan yang lebih rendah model VaR ini dapat diterima atau tidak. Seperti yang terlihat dari Tabel 4 di atas, untuk model VaR (95\%), hipotesis 2 juga ditolak untuk semua indeks saham. 


\begin{tabular}{|l|l|l|l|l|l|}
\hline \multirow{2}{*}{$\begin{array}{l}\text { Backtesting VaR } \\
\text { dengan GARCH }\end{array}$} & \multicolumn{2}{|l|}{ Total } & \multicolumn{2}{l|}{ Kriteria Kupiec } & \multirow{2}{*}{ Hasil } \\
\cline { 2 - 6 } & $99 \%$ & $95 \%$ & $99 \%$ & $95 \%$ & \\
\hline JKSE & 123 & 134 & $\mathrm{~N}<7$ & $6<\mathrm{N}<20$ & DITOLAK \\
\hline KLSE & 72 & 88 & $\mathrm{~N}<7$ & $6<\mathrm{N}<20$ & DITOLAK \\
\hline STI & 124 & 133 & $\mathrm{~N}<7$ & $6<\mathrm{N}<20$ & DITOLAK \\
\hline SSE & 115 & 121 & $\mathrm{~N}<7$ & $6<\mathrm{N}<20$ & DITOLAK \\
\hline PSEI & 136 & 143 & $\mathrm{~N}<7$ & $6<\mathrm{N}<20$ & DITOLAK \\
\hline HANGSENG & 144 & 154 & $\mathrm{~N}<7$ & $6<\mathrm{N}<20$ & DITOLAK \\
\hline NIKKEI & 173 & 180 & $\mathrm{~N}<7$ & $6<\mathrm{N}<20$ & DITOLAK \\
\hline KOSPI & 165 & 173 & $\mathrm{~N}<7$ & $6<\mathrm{N}<20$ & DITOLAK \\
\hline
\end{tabular}

JURNAL

MANAJEMEN

INDONESIA

Vol. 12 - No. 4

April 2013

Tabel 5.

Pengujian VaR

dengan pemodelan volatilitas $\mathrm{GARCH}$

Dari Tabel 5 terlihat bahwa untuk model VaR dengan tingkat kepercayaan 99\%, hipotesis 1 ditolak untuk semua indeks saham, hal ini dikarenakan Total Failure melebihi jumlah yang persyaratan Kupiec Criteria. Dikarenakan pada pemodelan VaR menggunakan tingkat kepercayaan 99\% semua indeks saham tidak memenuhi kriteria Kupiec, maka dilakukan lagi pemodelan baru dengan menggunakan tingkat kepercayaan sebesar 95\%. Hal ini dilakukan untuk mengetahui apakah dengan tingkat kepercayaan yang lebih rendah model VaR ini dapat diterima atau tidak. Seperti yang terlihat dari Tabel 5 di atas, untuk model VaR (95\%), hipotesis 2 juga ditolak untuk semua indeks saham.

\begin{tabular}{|l|l|l|l|l|l|}
\hline \multirow{2}{*}{$\begin{array}{l}\text { Backtesting VaR } \\
\text { Eengan }\end{array}$} & \multicolumn{2}{|l|}{$\begin{array}{l}\text { Total } \\
\text { Failure }\end{array}$} & \multicolumn{2}{l}{ Kriteria Kupiec } & \multirow{2}{*}{ Hasil } \\
\cline { 2 - 5 } & $99 \%$ & $95 \%$ & $99 \%$ & $95 \%$ & \\
\hline JKSE & 39 & 46 & $\mathrm{~N}<7$ & $6<\mathrm{N}<20$ & DITOLAK \\
\hline KLSE & 0 & - & $\mathrm{N}<7$ & - & DITERIMA \\
\hline STI & 0 & - & $\mathrm{N}<7$ & - & DITERIMA \\
\hline SSE & 0 & - & $\mathrm{N}<7$ & - & DITERIMA \\
\hline PSEI & 10 & 14 & $\mathrm{~N}<7$ & $6<\mathrm{N}<20$ & DITERIMA* \\
\hline HANGSENG & 0 & - & $\mathrm{N}<7$ & - & DITERIMA \\
\hline NIKKEI & 0 & - & $\mathrm{N}<7$ & - & DITERIMA \\
\hline KOSPI & 4 & - & $\mathrm{N}<7$ & - & DITERIMA \\
\hline
\end{tabular}

* Diterima pada tingkat kepercayaan 95\%

Dari Tabel 6 terlihat bahwa untuk model VaR dengan tingkat kepercayaan 99\%, hipotesis 1 diterima untuk semua indeks saham, kecuali untuk indeks saham JKSE dan PSEI hal ini dikarenakan Total Failure melebihi jumlah persyaratan Kupiec Criteria. Dikarenakan pada indeks saham JKSE dan PSEI hipotesis 1 ditolak, maka dilakukan lagi pemodelan baru dengan menggunakan tingkat kepercayaan sebesar 95\%. Hal ini dilakukan untuk mengetahui apakah dengan tingkat kepercayaan yang lebih rendah model VaR ini dapat diterima atau tidak. Seperti yang terlihat dari Tabel 6 di atas, untuk model VaR (95\%), hipotesis 2 juga ditolak untuk indeks saham JKSE, tetapi hipotesis 2 diterima untuk indeks saham PSEI. Pemodelan baru dengan tingkat kepercayaan 95\% hanya dilalukan pada indeks saham JKSE dan PSEI karena pada pengujian dengan tingkat kepercayaan 99\%, hipotesis 1 ditolak. Sedangkan untuk keenam saham lainnya hipotesis 1 diterima jadi tidak diperlukan lagi pemodelan baru dengan tingkat kepercayaan $95 \%$.

Tabel 6.

Pengujian VaR dengan pemodelan volatilitas EGARCH 


\section{c. Tahun 2007}

JURNAL MANAJEMEN INDONESIA

Vol. 12 - No. 4

April 2013

Tabel 7. Pengujian VaR dengan pemodelan volatilitas ARCH

\begin{tabular}{|l|l|l|l|l|l|}
\hline \multirow{2}{*}{$\begin{array}{l}\text { Backtesting VaR } \\
\text { dengan ARCH }\end{array}$} & \multicolumn{2}{|l|}{ Total } & \multicolumn{2}{l}{ Kriteria Kupiec } & \multirow{2}{*}{ Hasil } \\
\cline { 2 - 5 } & $99 \%$ & $95 \%$ & $99 \%$ & $95 \%$ & \\
\hline JKSE & 126 & 136 & $\mathrm{~N}<7$ & $6<\mathrm{N}<20$ & DITOLAK \\
\hline KLSE & 144 & 150 & $\mathrm{~N}<7$ & $6<\mathrm{N}<20$ & DITOLAK \\
\hline STI & 165 & 168 & $\mathrm{~N}<7$ & $6<\mathrm{N}<20$ & DITOLAK \\
\hline SSE & 143 & 151 & $\mathrm{~N}<7$ & $6<\mathrm{N}<20$ & DITOLAK \\
\hline PSEI & 151 & 157 & $\mathrm{~N}<7$ & $6<\mathrm{N}<20$ & DITOLAK \\
\hline HANGSENG & 157 & 165 & $\mathrm{~N}<7$ & $6<\mathrm{N}<20$ & DITOLAK \\
\hline NIKKEI & 177 & 188 & $\mathrm{~N}<7$ & $6<\mathrm{N}<20$ & DITOLAK \\
\hline KOSPI & 140 & 148 & $\mathrm{~N}<7$ & $6<\mathrm{N}<20$ & DITOLAK \\
\hline
\end{tabular}

Dari Tabel 7 terlihat bahwa untuk model VaR dengan tingkat kepercayaan 99\%, hipotesis 1 ditolak untuk semua indeks saham, hal ini dikarenakan Total Failure melebihi jumlah yang persyaratan Kupiec Criteria. Dikarenakan pada pemodelan VaR menggunakan tingkat kepercayaan 99\% semua indeks saham tidak memenuhi kriteria Kupiec, maka dilakukan lagi pemodelan baru dengan menggunakan tingkat kepercayaan sebesar 95\%. Hal ini dilakukan untuk mengetahui apakah dengan tingkat kepercayaan yang lebih rendah model VaR ini dapat diterima atau tidak. Seperti yang terlihat dari Tabel 7 di atas, untuk model VaR (95\%), hipotesis 2 juga ditolak untuk semua indeks saham.

\begin{tabular}{|c|c|c|c|c|c|}
\hline \multirow{2}{*}{$\begin{array}{l}\text { Backtesting VaR } \\
\text { dengan GARCH }\end{array}$} & \multicolumn{2}{|c|}{$\begin{array}{l}\text { Total } \\
\text { Failure }\end{array}$} & \multicolumn{2}{|c|}{ Kriteria Kupiec } & \multirow{2}{*}{ Hasil } \\
\hline & $99 \%$ & $95 \%$ & $99 \%$ & $95 \%$ & \\
\hline JKSE & 137 & 144 & $\mathrm{~N}<7$ & $6<N<20$ & DITOLAK \\
\hline KLSE & 132 & 142 & $\mathrm{~N}<7$ & $6<N<20$ & DITOLAK \\
\hline STI & 160 & 165 & $\mathrm{~N}<7$ & $6<N<20$ & DITOLAK \\
\hline SSE & 138 & 146 & $\mathrm{~N}<7$ & $6<\mathrm{N}<20$ & DITOLAK \\
\hline PSEI & 148 & 158 & $\mathrm{~N}<7$ & $6<N<20$ & DITOLAK \\
\hline HANGSENG & 159 & 164 & $\mathrm{~N}<7$ & $6<\mathrm{N}<20$ & DITOLAK \\
\hline NIKKEI & 185 & 190 & $\mathrm{~N}<7$ & $6<N<20$ & DITOLAK \\
\hline KOSPI & 146 & 151 & $N<7$ & $6<\mathrm{N}<20$ & DITOLAK \\
\hline
\end{tabular}

Pengujian VaR dengan pemodelan volatilitas GARCH

\section{8} 1 ditolak untuk semua indeks saham, hal ini dikarenakan Total Failure melebihi jumlah yang persyaratan Kupiec Criteria. Dikarenakan pada pemodelan VaR menggunakan tingkat kepercayaan 99\% semua indeks saham tidak memenuhi kriteria Kupiec, maka dilakukan lagi pemodelan baru dengan menggunakan tingkat kepercayaan sebesar 95\%. Hal ini dilakukan untuk mengetahui apakah dengan tingkat kepercayaan yang lebih rendah model VaR ini dapat diterima atau tidak. Seperti yang terlihat dari Tabel 8 di atas, untuk model VaR (95\%), hipotesis 2 juga ditolak untuk semua indeks saham. 


\begin{tabular}{|l|l|l|l|l|l|}
\hline \multirow{2}{*}{$\begin{array}{l}\text { Backtesting VaR } \\
\text { dengan }\end{array}$} & \multicolumn{2}{|l|}{$\begin{array}{l}\text { Total } \\
\text { EGAilure }\end{array}$} & \multicolumn{2}{l|}{ Kriteria Kupiec } & Hasil \\
\cline { 2 - 5 } & $99 \%$ & $95 \%$ & $99 \%$ & $95 \%$ & \\
\hline JKSE & 51 & 63 & $\mathrm{~N}<7$ & $6<\mathrm{N}<20$ & DITOLAK \\
\hline KLSE & 0 & - & $\mathrm{N}<7$ & - & DITERIMA \\
\hline STI & 0 & - & $\mathrm{N}<7$ & - & DITERIMA \\
\hline SSE & 0 & - & $\mathrm{N}<7$ & - & DITERIMA \\
\hline PSEI & 22 & 32 & $\mathrm{~N}<7$ & $6<\mathrm{N}<20$ & DITOLAK \\
\hline HANGSENG & 0 & - & $\mathrm{N}<7$ & - & DITERIMA \\
\hline NIKKEI & 0 & - & $\mathrm{N}<7$ & - & DITERIMA \\
\hline KOSPI & 14 & 26 & $\mathrm{~N}<7$ & $6<\mathrm{N}<20$ & DITOLAK \\
\hline
\end{tabular}

JURNAL

MANAJEMEN

INDONESIA

Vol. 12 - No. 4

April 2013

Dari Tabel 9 terlihat bahwa untuk model VaR dengan tingkat kepercayaan 99\%, hipotesis 1 diterima untuk 5 indeks saham, kecuali untuk indeks saham JKSE, PSEI dan KOSPI hal ini dikarenakan Total Failure melebihi jumlah persyaratan Kupiec Criteria. Dikarenakan pada indeks saham JKSE, PSEI dan KOSPI hipotesis 1 ditolak, maka dilakukan lagi pemodelan baru dengan menggunakan tingkat kepercayaan sebesar 95\%. Hal ini dilakukan untuk mengetahui apakah dengan tingkat kepercayaan yang lebih rendah model VaR ini dapat diterima atau tidak. Seperti yang terlihat dari Tabel 9 di atas, untuk model VaR (95\%), hipotesis 2 juga ditolak untuk indeks saham JKSE, PSEI dan KOSPI. Pemodelan baru dengan tingkat kepercayaan $95 \%$ hanya dilalukan pada indeks saham JKSE, PSEI dan KOSPI karena pada pengujian dengan tingkat kepercayaan 99\%, hipotesis 1 ditolak. Sedangkan untuk kelima saham lainnya hipotesis 1 diterima jadi tidak diperlukan lagi pemodelan baru dengan tingkat kepercayaan 95\%.

\section{d. Tahun 2008}

\begin{tabular}{|l|c|c|c|c|c|}
\hline \multirow{2}{*}{$\begin{array}{l}\text { Backtesting VaR } \\
\text { dengan ARCH }\end{array}$} & \multicolumn{2}{|l|}{$\begin{array}{l}\text { Total } \\
\text { Failure }\end{array}$} & Kriteria Kupiec & Hasil \\
\cline { 2 - 5 } & $99 \%$ & $95 \%$ & $99 \%$ & $95 \%$ & \\
\hline JKSE & 187 & 192 & $\mathrm{~N}<7$ & $6<\mathrm{N}<20$ & DITOLAK \\
\hline KLSE & 198 & 201 & $\mathrm{~N}<7$ & $6<\mathrm{N}<20$ & DITOLAK \\
\hline STI & 198 & 202 & $\mathrm{~N}<7$ & $6<\mathrm{N}<20$ & DITOLAK \\
\hline SSE & 218 & 222 & $\mathrm{~N}<7$ & $6<\mathrm{N}<20$ & DITOLAK \\
\hline PSEI & 192 & 195 & $\mathrm{~N}<7$ & $6<\mathrm{N}<20$ & DITOLAK \\
\hline HANGSENG & 203 & 206 & $\mathrm{~N}<7$ & $6<\mathrm{N}<20$ & DITOLAK \\
\hline NIKKEI & 196 & 198 & $\mathrm{~N}<7$ & $6<\mathrm{N}<20$ & DITOLAK \\
\hline KOSPI & 190 & 196 & $\mathrm{~N}<7$ & $6<\mathrm{N}<20$ & DITOLAK \\
\hline
\end{tabular}

Tabel 10.

Pengujian VaR dengan pemodelan volatilitas $\mathrm{ARCH}$

Dari Tabel 10 terlihat bahwa untuk model VaR dengan tingkat kepercayaan 99\%, hipotesis 1 ditolak untuk semua indeks saham, hal ini dikarenakan Total Failure melebihi jumlah yang persyaratan Kupiec Criteria. Dikarenakan pada pemodelan VaR menggunakan tingkat kepercayaan 99\% semua indeks saham tidak memenuhi kriteria Kupiec, maka dilakukan lagi pemodelan baru dengan menggunakan tingkat kepercayaan sebesar 95\%. Hal ini dilakukan untuk mengetahui apakah dengan tingkat kepercayaan yang lebih rendah model VaR ini dapat diterima atau tidak. Seperti yang terlihat dari Tabel 10 di atas, untuk model VaR (95\%), hipotesis 2 juga ditolak untuk semua indeks saham. 
JURNAL

MANAJEMEN

INDONESIA

Vol. 12 - No. 4

April 2013

Tabel 11

Pengujian VaR dengan pemodelan volatilitas GARCH

\begin{tabular}{|l|l|l|l|l|l|}
\hline \multirow{2}{*}{$\begin{array}{l}\text { Backtesting VaR } \\
\text { dengan GARCH }\end{array}$} & \multicolumn{2}{|l|}{$\begin{array}{l}\text { Total } \\
\text { Failure }\end{array}$} & \multicolumn{2}{l}{ Kriteria Kupiec } & \multirow{2}{*}{} \\
\cline { 2 - 5 } & $99 \%$ & $95 \%$ & $99 \%$ & $95 \%$ & \\
\hline JKSE & 182 & 189 & $\mathrm{~N}<7$ & $6<\mathrm{N}<20$ & DITOLAK \\
\hline KLSE & 193 & 198 & $\mathrm{~N}<7$ & $6<\mathrm{N}<20$ & DITOLAK \\
\hline STI & 196 & 201 & $\mathrm{~N}<7$ & $6<\mathrm{N}<20$ & DITOLAK \\
\hline SSE & 213 & 219 & $\mathrm{~N}<7$ & $6<\mathrm{N}<20$ & DITOLAK \\
\hline PSEI & 190 & 194 & $\mathrm{~N}<7$ & $6<\mathrm{N}<20$ & DITOLAK \\
\hline HANGSENG & 201 & 204 & $\mathrm{~N}<7$ & $6<\mathrm{N}<20$ & DITOLAK \\
\hline NIKKEI & 193 & 195 & $\mathrm{~N}<7$ & $6<\mathrm{N}<20$ & DITOLAK \\
\hline KOSPI & 189 & 194 & $\mathrm{~N}<7$ & $6<\mathrm{N}<20$ & DITOLAK \\
\hline
\end{tabular}

Dari Tabel 11 terlihat bahwa untuk model VaR dengan tingkat kepercayaan 99\%, hipotesis 1 ditolak untuk semua indeks saham, hal ini dikarenakan Total Failure melebihi jumlah yang persyaratan Kupiec Criteria. Dikarenakan pada pemodelan VaR menggunakan tingkat kepercayaan 99\% semua indeks saham tidak memenuhi kriteria Kupiec, maka dilakukan lagi pemodelan baru dengan menggunakan tingkat kepercayaan sebesar 95\%. Hal ini dilakukan untuk mengetahui apakah dengan tingkat kepercayaan yang lebih rendah model VaR ini dapat diterima atau tidak. Seperti yang terlihat dari Tabel 11 di atas, untuk model VaR (95\%), hipotesis 2 juga ditolak untuk semua indeks saham.

\begin{tabular}{|c|c|c|c|c|c|}
\hline \multirow{2}{*}{$\begin{array}{l}\text { Backtesting VaR } \\
\text { dengan } \\
\text { EGARCH }\end{array}$} & \multicolumn{2}{|c|}{$\begin{array}{l}\text { Total } \\
\text { Failure }\end{array}$} & \multicolumn{2}{|c|}{ Kriteria Kupiec } & \multirow[t]{2}{*}{ Hasil } \\
\hline & $99 \%$ & $95 \%$ & $99 \%$ & $95 \%$ & \\
\hline JKSE & 124 & 142 & $\mathrm{~N}<7$ & $6<\mathrm{N}<20$ & DITOLAK \\
\hline KLSE & 0 & - & $N<7$ & - & DITERIMA \\
\hline STI & 20 & 36 & $\mathrm{~N}<7$ & $6<\mathrm{N}<20$ & DITOLAK \\
\hline SSE & 0 & - & $\mathrm{N}<7$ & - & DITERIMA \\
\hline PSEI & 46 & 66 & $N<7$ & $6<N<20$ & DITOLAK \\
\hline HANGSENG & 2 & - & $\mathrm{N}<7$ & - & DITERIMA \\
\hline NIKKEI & 14 & 21 & $N<7$ & $6<\mathrm{N}<20$ & DITOLAK \\
\hline KOSPI & 43 & 64 & $\mathrm{~N}<7$ & $6<\mathrm{N}<20$ & DITOLAK \\
\hline
\end{tabular}

Dari Tabel 12 terlihat bahwa untuk model VaR dengan tingkat kepercayaan 99\%, hipotesis 1 hanya diterima untuk tiga indeks saham yaitu KLSE, SSE, dan HANGSENG, hal ini dikarenakan Total Failure ketiga indeks saham tersebut kurang dari jumlah persyaratan Kupiec Criteria. Dikarenakan pada kelima indeks lainnya hipotesis 1 ditolak, maka dilakukan lagi pemodelan baru dengan menggunakan tingkat kepercayaan sebesar 95\%. Hal ini dilakukan untuk mengetahui apakah dengan tingkat kepercayaan yang lebih rendah model VaR ini dapat diterima atau tidak. Seperti yang terlihat dari Tabel 12 di atas, untuk model VaR (95\%), hipotesis 2 juga ditolak untuk indeks saham JKSE, STI, PSEI, NIKKEI dan KOSPI. 


\begin{tabular}{|l|l|l|l|l|l|}
\hline \multirow{2}{*}{$\begin{array}{l}\text { Backtesting VaR } \\
\text { dengan ARCH }\end{array}$} & \multicolumn{2}{|l|}{$\begin{array}{l}\text { Total } \\
\text { Failure }\end{array}$} & \multirow{2}{*}{ Hasil } \\
\cline { 2 - 5 } & $99 \%$ & $95 \%$ & $99 \%$ & $95 \%$ & \\
\hline JKSE & 157 & 163 & $\mathrm{~N}<7$ & $6<\mathrm{N}<20$ & DITOLAK \\
\hline KLSE & 131 & 135 & $\mathrm{~N}<7$ & $6<\mathrm{N}<20$ & DITOLAK \\
\hline STI & 167 & 177 & $\mathrm{~N}<7$ & $6<\mathrm{N}<20$ & DITOLAK \\
\hline SSE & 134 & 144 & $\mathrm{~N}<7$ & $6<\mathrm{N}<20$ & DITOLAK \\
\hline PSEI & 151 & 156 & $\mathrm{~N}<7$ & $6<\mathrm{N}<20$ & DITOLAK \\
\hline HANGSENG & 171 & 180 & $\mathrm{~N}<7$ & $6<\mathrm{N}<20$ & DITOLAK \\
\hline NIKKEI & 170 & 175 & $\mathrm{~N}<7$ & $6<\mathrm{N}<20$ & DITOLAK \\
\hline KOSPI & 154 & 164 & $\mathrm{~N}<7$ & $6<\mathrm{N}<20$ & DITOLAK \\
\hline
\end{tabular}

JURNAL

MANAJEMEN

INDONESIA

Vol. 12 - No. 4

April 2013

Tabel 13.

Pengujian VaR

dengan pemodelan volatilitas $\mathrm{ARCH}$

Dari Tabel 13 terlihat bahwa untuk model VaR dengan tingkat kepercayaan 99\%, hipotesis 1 ditolak untuk semua indeks saham, hal ini dikarenakan Total Failure melebihi jumlah yang persyaratan Kupiec Criteria. Dikarenakan pada pemodelan VaR menggunakan tingkat kepercayaan 99\% semua indeks saham tidak memenuhi kriteria Kupiec, maka dilakukan lagi pemodelan baru dengan menggunakan tingkat kepercayaan sebesar 95\%. Hal ini dilakukan untuk mengetahui apakah dengan tingkat kepercayaan yang lebih rendah model VaR ini dapat diterima atau tidak. Seperti yang terlihat dari Tabel 13 di atas, untuk model VaR (95\%), hipotesis 2 juga ditolak untuk semua indeks saham.

\begin{tabular}{|c|c|c|c|c|c|}
\hline \multirow[t]{2}{*}{$\begin{array}{l}\text { Backtesting VaR } \\
\text { dengan GARCH }\end{array}$} & \multicolumn{2}{|c|}{$\begin{array}{l}\text { Total } \\
\text { Failure }\end{array}$} & \multicolumn{2}{|c|}{ Kriteria Kupiec } & \multirow[t]{2}{*}{ Hasil } \\
\hline & $99 \%$ & $95 \%$ & $99 \%$ & $95 \%$ & \\
\hline JKSE & 155 & 161 & $\mathrm{~N}<7$ & $6<\mathrm{N}<20$ & DITOLAK \\
\hline KLSE & 126 & 134 & $\mathrm{~N}<7$ & $6<N<20$ & DITOLAK \\
\hline STI & 168 & 176 & $\mathrm{~N}<7$ & $6<N<20$ & DITOLAK \\
\hline SSE & 135 & 140 & $\mathrm{~N}<7$ & $6<N<20$ & DITOLAK \\
\hline PSEI & 150 & 156 & $N<7$ & $6<N<20$ & DITOLAK \\
\hline HANGSENG & 174 & 179 & $\mathrm{~N}<7$ & $6<N<20$ & DITOLAK \\
\hline NIKKEI & 171 & 172 & $\mathrm{~N}<7$ & $6<N<20$ & DITOLAK \\
\hline KOSPI & 156 & 164 & $N<7$ & $6<N<20$ & DITOLAK \\
\hline
\end{tabular}

Dari Tabel 14 terlihat bahwa untuk model VaR dengan tingkat kepercayaan 99\%, hipotesis 1 ditolak untuk semua indeks saham, hal ini dikarenakan Total Failure melebihi jumlah yang persyaratan Kupiec Criteria. Dikarenakan pada pemodelan VaR menggunakan tingkat kepercayaan 99\% semua indeks saham tidak memenuhi kriteria Kupiec, maka dilakukan lagi pemodelan baru dengan menggunakan tingkat kepercayaan sebesar 95\%. Hal ini dilakukan untuk mengetahui apakah dengan tingkat kepercayaan yang lebih rendah model VaR ini dapat diterima atau tidak. Seperti yang terlihat dari Tabel 14 di atas, untuk model VaR (95\%), hipotesis 2 juga ditolak untuk semua indeks saham.

Tabel 14.

Pengujian VaR dengan pemodelan volatilitas GARCH

\section{1}


JURNAL

MANAJEMEN

INDONESIA

Vol. 12 - No. 4

April 2013

Tabel 15.

Pengujian VaR

dengan pemodelan

volatilitas EGARCH

\begin{tabular}{|c|c|c|c|c|c|}
\hline \multirow{2}{*}{$\begin{array}{l}\text { Backtesting VaR } \\
\text { dengan } \\
\text { EGARCH }\end{array}$} & \multicolumn{2}{|c|}{$\begin{array}{l}\text { Total } \\
\text { Failure }\end{array}$} & \multicolumn{2}{|c|}{ Kriteria Kupiec } & \multirow[t]{2}{*}{ Hasil } \\
\hline & $99 \%$ & $95 \%$ & $99 \%$ & $95 \%$ & \\
\hline JKSE & 42 & 76 & $N<7$ & $6<\mathrm{N}<20$ & DITOLAK \\
\hline KLSE & 0 & - & $N<7$ & - & DITERIMA \\
\hline STI & 0 & - & $\mathrm{N}<7$ & - & DITERIMA \\
\hline SSE & 0 & - & $N<7$ & - & DITERIMA \\
\hline PSEI & 0 & - & $\mathrm{N}<7$ & & DITERIMA \\
\hline HANGSENG & 0 & - & $\mathrm{N}<7$ & - & DITERIMA \\
\hline NIKKEI & 0 & - & $\mathrm{N}<7$ & - & DITERIMA \\
\hline KOSPI & 9 & 18 & $\mathrm{~N}<7$ & $6<\mathrm{N}<20$ & DITERIMA* \\
\hline
\end{tabular}

*DITERIMA pada tingkat kepercayaan 95\%

Dari Tabel 15 terlihat bahwa untuk model VaR dengan tingkat kepercayaan 99\%, hipotesis 1 diterima untuk semua indeks saham, kecuali untuk indeks saham JKSE dan KOSPI hal ini dikarenakan Total Failure melebihi jumlah persyaratan Kupiec Criteria. Dikarenakan pada indeks saham JKSE dan KOSPI hipotesis 1 ditolak, maka dilakukan lagi pemodelan baru dengan menggunakan tingkat kepercayaan sebesar 95\%. Hal ini dilakukan untuk mengetahui apakah dengan tingkat kepercayaan yang lebih rendah model VaR ini dapat diterima atau tidak. Seperti yang terlihat dari Tabel 15 di atas, untuk model VaR (95\%), hipotesis 2 juga ditolak untuk indeks saham JKSE, tetapi hipotesis 2 diterima untuk indeks saham KOSPI. Pemodelan baru dengan tingkat kepercayaan $95 \%$ hanya dilalukan pada indeks saham JKSE dan KOSPI karena pada pengujian dengan tingkat kepercayaan 99\%, hipotesis 1 ditolak. Sedangkan untuk keenam saham lainnya hipotesis 1 diterima jadi tidak diperlukan lagi pemodelan baru dengan tingkat kepercayaan $95 \%$.

\section{f. Tahun $\mathbf{2 0 1 0}$}

Tabel 16.

Pengujian VaR dengan pemodelan volatilitas $A R C H$

\begin{tabular}{|l|l|l|l|l|l|}
\hline \multirow{2}{*}{$\begin{array}{l}\text { Backtesting VaR } \\
\text { dengan ARCH }\end{array}$} & \multicolumn{2}{|l|}{$\begin{array}{l}\text { Total } \\
\text { Failure }\end{array}$} & \multicolumn{2}{l}{ Kriteria Kupiec } & \multirow{2}{*}{} \\
\cline { 2 - 5 } & $99 \%$ & $95 \%$ & $99 \%$ & $95 \%$ & \\
\hline JKSE & 137 & 146 & $\mathrm{~N}<7$ & $6<\mathrm{N}<20$ & DITOLAK \\
\hline KLSE & 116 & 128 & $\mathrm{~N}<7$ & $6<\mathrm{N}<20$ & DITOLAK \\
\hline STI & 137 & 151 & $\mathrm{~N}<7$ & $6<\mathrm{N}<20$ & DITOLAK \\
\hline SSE & 176 & 183 & $\mathrm{~N}<7$ & $6<\mathrm{N}<20$ & DITOLAK \\
\hline PSEI & 140 & 152 & $\mathrm{~N}<7$ & $6<\mathrm{N}<20$ & DITOLAK \\
\hline HANGSENG & 160 & 166 & $\mathrm{~N}<7$ & $6<\mathrm{N}<20$ & DITOLAK \\
\hline NIKKEI & 163 & 168 & $\mathrm{~N}<7$ & $6<\mathrm{N}<20$ & DITOLAK \\
\hline KOSPI & 135 & 146 & $\mathrm{~N}<7$ & $6<\mathrm{N}<20$ & DITOLAK \\
\hline
\end{tabular}

Dari Tabel 16 terlihat bahwa untuk model VaR dengan tingkat kepercayaan 99\%, hipotesis 1 ditolak untuk semua indeks saham, hal ini dikarenakan Total Failure melebihi jumlah yang persyaratan Kupiec Criteria. Dikarenakan pada pemodelan VaR menggunakan tingkat kepercayaan 99\% semua indeks saham tidak memenuhi kriteria Kupiec, maka dilakukan lagi pemodelan baru dengan menggunakan tingkat kepercayaan sebesar 95\%. Hal ini dilakukan untuk mengetahui apakah dengan tingkat kepercayaan yang lebih rendah model VaR ini dapat diterima atau tidak. Seperti yang terlihat dari Tabel 16 di atas, untuk model VaR (95\%), hipotesis 2 juga ditolak untuk semua indeks saham. 


\begin{tabular}{|l|l|l|l|l|l|}
\hline \multirow{2}{*}{$\begin{array}{l}\text { Backtesting VaR } \\
\text { dengan GARCH }\end{array}$} & \multicolumn{2}{|l|}{$\begin{array}{l}\text { Total } \\
\text { Failure }\end{array}$} & Kriteria Kupiec & \multirow{2}{*}{ Hasil } \\
\cline { 2 - 5 } & $99 \%$ & $95 \%$ & $99 \%$ & $95 \%$ & \\
\hline JKSE & 143 & 151 & $\mathrm{~N}<7$ & $6<\mathrm{N}<20$ & DITOLAK \\
\hline KLSE & 100 & 117 & $\mathrm{~N}<7$ & $6<\mathrm{N}<20$ & DITOLAK \\
\hline STI & 147 & 160 & $\mathrm{~N}<7$ & $6<\mathrm{N}<20$ & DITOLAK \\
\hline SSE & 181 & 189 & $\mathrm{~N}<7$ & $6<\mathrm{N}<20$ & DITOLAK \\
\hline PSEI & 140 & 152 & $\mathrm{~N}<7$ & $6<\mathrm{N}<20$ & DITOLAK \\
\hline HANGSENG & 166 & 172 & $\mathrm{~N}<7$ & $6<\mathrm{N}<20$ & DITOLAK \\
\hline NIKKEI & 164 & 171 & $\mathrm{~N}<7$ & $6<\mathrm{N}<20$ & DITOLAK \\
\hline KOSPI & 146 & 154 & $\mathrm{~N}<7$ & $6<\mathrm{N}<20$ & DITOLAK \\
\hline
\end{tabular}

JURNAL

MANAJEMEN

INDONESIA

Vol. 12 - No. 4

April 2013

Tabel 17.

Pengujian VaR dengan pemodelan volatilitas GARCH

Dari Tabel 17 terlihat bahwa untuk model VaR dengan tingkat kepercayaan 99\%, hipotesis 1 ditolak untuk semua indeks saham, hal ini dikarenakan Total Failure melebihi jumlah yang persyaratan Kupiec Criteria. Dikarenakan pada pemodelan VaR menggunakan tingkat kepercayaan 99\% semua indeks saham tidak memenuhi kriteria Kupiec, maka dilakukan lagi pemodelan baru dengan menggunakan tingkat kepercayaan sebesar 95\%. Hal ini dilakukan untuk mengetahui apakah dengan tingkat kepercayaan yang lebih rendah model VaR ini dapat diterima atau tidak. Seperti yang terlihat dari Tabel 17 di atas, untuk model VaR (95\%), hipotesis 2 juga ditolak untuk semua indeks saham.

\begin{tabular}{|l|l|l|l|l|l|}
\hline \multirow{2}{*}{$\begin{array}{l}\text { Backtesting VaR } \\
\text { EGAREn }\end{array}$} & \multicolumn{2}{|l|}{$\begin{array}{l}\text { Total } \\
\text { Failure }\end{array}$} & \multicolumn{2}{l|}{ Kriteria Kupiec } & Hasil \\
\cline { 2 - 5 } & $99 \%$ & $95 \%$ & $99 \%$ & $95 \%$ & \\
\hline JKSE & 41 & 61 & $\mathrm{~N}<7$ & $6<\mathrm{N}<20$ & DITOLAK \\
\hline KLSE & 0 & - & $\mathrm{N}<7$ & - & DITERIMA \\
\hline STI & 0 & - & $\mathrm{N}<7$ & - & DITERIMA \\
\hline SSE & 0 & - & $\mathrm{N}<7$ & - & DITERIMA \\
\hline PSEI & 1 & - & $\mathrm{N}<7$ & - & DITERIMA \\
\hline HANGSENG & 0 & - & $\mathrm{N}<7$ & - & DITERIMA \\
\hline NIKKEI & 0 & - & $\mathrm{N}<7$ & - & DITERIMA \\
\hline KOSPI & 0 & - & $\mathrm{N}<7$ & - & DITERIMA \\
\hline
\end{tabular}

Dari Tabel 18 terlihat bahwa untuk model VaR dengan tingkat kepercayaan 99\%, hipotesis 1 diterima untuk semua indeks saham, kecuali untuk indeks saham JKSE hal ini dikarenakan Total Failure melebihi jumlah persyaratan Kupiec Criteria. Dikarenakan pada indeks saham JKSE hipotesis 1 ditolak, maka dilakukan lagi pemodelan baru dengan menggunakan tingkat kepercayaan sebesar 95\%. Hal ini dilakukan untuk mengetahui apakah dengan tingkat kepercayaan yang lebih rendah model VaR ini dapat diterima atau tidak. Seperti yang terlihat dari Tabel 18 di atas, untuk model VaR (95\%), hipotesis 2 juga ditolak untuk indeks saham JKSE, Pemodelan baru dengan tingkat kepercayaan 95\% hanya dilalukan pada indeks saham JKSE karena pada pengujian dengan tingkat kepercayaan 99\%, hipotesis 1 ditolak. Sedangkan untuk ketujuh saham lainnya hipotesis 1 diterima jadi tidak diperlukan lagi pemodelan baru dengan tingkat kepercayaan 95\%.

Tabel 18.

Pengujian VaR dengan pemodelan volatilitas EGARCH

\section{3}




\section{g. Tahun 2011}

JURNAL MANAJEMEN INDONESIA

Vol. 12 - No. 4

April 2013

Tabel 19.

Pengujian VaR dengan pemodelan volatilitas $\mathrm{ARCH}$

Tabel 20 Pengujian VaR dengan pemodelan volatilitas GARCH

\begin{tabular}{|l|l|l|l|l|l|}
\hline \multirow{2}{*}{$\begin{array}{l}\text { Backtesting VaR } \\
\text { dengan ARCH }\end{array}$} & \multicolumn{2}{|l|}{$\begin{array}{l}\text { Total } \\
\text { Failure }\end{array}$} & Kriteria Kupiec & \multirow{2}{*}{ Hasil } \\
\cline { 2 - 5 } & $99 \%$ & $95 \%$ & $99 \%$ & $95 \%$ & \\
\hline JKSE & 146 & 161 & $\mathrm{~N}<7$ & $6<\mathrm{N}<20$ & DITOLAK \\
\hline KLSE & 149 & 160 & $\mathrm{~N}<7$ & $6<\mathrm{N}<20$ & DITOLAK \\
\hline STI & 187 & 194 & $\mathrm{~N}<7$ & $6<\mathrm{N}<20$ & DITOLAK \\
\hline SSE & 195 & 204 & $\mathrm{~N}<7$ & $6<\mathrm{N}<20$ & DITOLAK \\
\hline PSEI & 154 & 162 & $\mathrm{~N}<7$ & $6<\mathrm{N}<20$ & DITOLAK \\
\hline HANGSENG & 187 & 192 & $\mathrm{~N}<7$ & $6<\mathrm{N}<20$ & DITOLAK \\
\hline NIKKEI & 189 & 197 & $\mathrm{~N}<7$ & $6<\mathrm{N}<20$ & DITOLAK \\
\hline KOSPI & 187 & 189 & $\mathrm{~N}<7$ & $6<\mathrm{N}<20$ & DITOLAK \\
\hline
\end{tabular}

Dari Tabel 19 terlihat bahwa untuk model VaR dengan tingkat kepercayaan 99\%, hipotesis 1 ditolak untuk semua indeks saham, hal ini dikarenakan Total Failure melebihi jumlah yang persyaratan Kupiec Criteria. Dikarenakan pada pemodelan VaR menggunakan tingkat kepercayaan 99\% semua indeks saham tidak memenuhi kriteria Kupiec, maka dilakukan lagi pemodelan baru dengan menggunakan tingkat kepercayaan sebesar 95\%. Hal ini dilakukan untuk mengetahui apakah dengan tingkat kepercayaan yang lebih rendah model VaR ini dapat diterima atau tidak. Seperti yang terlihat dari Tabel 19 di atas, untuk model VaR (95\%), hipotesis 2 juga ditolak untuk semua indeks saham.

\begin{tabular}{|l|l|l|l|l|l|}
\hline \multirow{2}{*}{$\begin{array}{l}\text { Backtesting VaR } \\
\text { dengan GARCH }\end{array}$} & \multicolumn{2}{|l|}{$\begin{array}{l}\text { Total } \\
\text { Failure }\end{array}$} & \multicolumn{2}{l}{ Hasileria Kupiec } \\
\cline { 2 - 5 } & $99 \%$ & $95 \%$ & $99 \%$ & $95 \%$ & \\
\hline JKSE & 156 & 163 & $\mathrm{~N}<7$ & $6<\mathrm{N}<20$ & DITOLAK \\
\hline KLSE & 142 & 150 & $\mathrm{~N}<7$ & $6<\mathrm{N}<20$ & DITOLAK \\
\hline STI & 190 & 196 & $\mathrm{~N}<7$ & $6<\mathrm{N}<20$ & DITOLAK \\
\hline SSE & 203 & 208 & $\mathrm{~N}<7$ & $6<\mathrm{N}<20$ & DITOLAK \\
\hline PSEI & 156 & 164 & $\mathrm{~N}<7$ & $6<\mathrm{N}<20$ & DITOLAK \\
\hline HANGSENG & 187 & 199 & $\mathrm{~N}<7$ & $6<\mathrm{N}<20$ & DITOLAK \\
\hline NIKKEI & 189 & 197 & $\mathrm{~N}<7$ & $6<\mathrm{N}<20$ & DITOLAK \\
\hline KOSPI & 185 & 191 & $\mathrm{~N}<7$ & $6<\mathrm{N}<20$ & DITOLAK \\
\hline
\end{tabular}

Dari Tabel 20 terlihat bahwa untuk model VaR dengan tingkat kepercayaan 99\%, hipotesis 1 ditolak untuk semua indeks saham, hal ini dikarenakan Total Failure melebihi jumlah yang persyaratan Kupiec Criteria. Dikarenakan pada pemodelan VaR menggunakan tingkat kepercayaan 99\% semua indeks saham tidak memenuhi kriteria Kupiec, maka dilakukan lagi pemodelan baru dengan menggunakan tingkat kepercayaan sebesar 95\%. Hal ini dilakukan untuk mengetahui apakah dengan tingkat kepercayaan yang lebih rendah model VaR ini dapat diterima atau tidak. Seperti yang terlihat dari Tabel 20 di atas, untuk model VaR (95\%), hipotesis 2 juga ditolak untuk semua indeks saham. 


\begin{tabular}{|c|c|c|c|c|c|}
\hline \multirow{2}{*}{$\begin{array}{l}\text { Backtesting VaR } \\
\text { dengan } \\
\text { EGARCH }\end{array}$} & \multicolumn{2}{|c|}{$\begin{array}{l}\text { Total } \\
\text { Failure }\end{array}$} & \multicolumn{2}{|c|}{ Kriteria Kupiec } & \multirow[t]{2}{*}{ Hasil } \\
\hline & $99 \%$ & $95 \%$ & $99 \%$ & $95 \%$ & \\
\hline JKSE & 45 & 64 & $\mathrm{~N}<7$ & $6<\mathrm{N}<20$ & DITOLAK \\
\hline KLSE & 0 & - & $\mathrm{N}<7$ & - & DITERIMA \\
\hline STI & 0 & - & $\mathrm{N}<7$ & - & DITERIMA \\
\hline SSE & 0 & - & $\mathrm{N}<7$ & - & DITERIMA \\
\hline PSEI & 9 & 15 & $\mathrm{~N}<7$ & $6<\mathrm{N}<20$ & DITERIMA* \\
\hline HANGSENG & 0 & - & $\mathrm{N}<7$ & - & DITERIMA \\
\hline NIKKEI & 4 & - & $\mathrm{N}<7$ & - & DITERIMA \\
\hline KOSPI & 18 & 29 & $\mathrm{~N}<7$ & $6<\mathrm{N}<20$ & DITOLAK \\
\hline
\end{tabular}

*DITERIMA pada tingkat kepercayaan 95\%
JURNAL

MANAJEMEN

INDONESIA

Vol. 12 - No. 4

April 2013

Tabel 21.

Pengujian VaR dengan pemodelan volatilitas GARCH

Dari Tabel 21 terlihat bahwa untuk model VaR dengan tingkat kepercayaan 99\%, hipotesis 1 diterima untuk kelima indeks saham, kecuali untuk indeks saham JKSE, PSEI dan KOSPI hal ini dikarenakan Total Failure melebihi jumlah persyaratan Kupiec Criteria. Dikarenakan pada indeks saham JKSE, PSEI dan KOSPI hipotesis 1 ditolak, maka dilakukan lagi pemodelan baru dengan menggunakan tingkat kepercayaan sebesar 95\%. Hal ini dilakukan untuk mengetahui apakah dengan tingkat kepercayaan yang lebih rendah model VaR ini dapat diterima atau tidak. Seperti yang terlihat dari Tabel 21 di atas, untuk model VaR (95\%), hipotesis 2 juga ditolak untuk indeks saham JKSE dan KOSPI, tetapi hipotesis 2 diterima untuk indeks saham PSEI. Pemodelan baru dengan tingkat kepercayaan 95\% hanya dilalukan pada indeks saham JKSE, PSEI dan KOSPI karena pada pengujian dengan tingkat kepercayaan 99\%, hipotesis 1 ditolak. Sedangkan untuk kelima saham lainnya hipotesis 1 diterima jadi tidak diperlukan lagi pemodelan baru dengan tingkat kepercayaan 95\%.

\section{h. Tahun 2012}

\begin{tabular}{|c|c|c|c|c|c|}
\hline \multirow[t]{2}{*}{$\begin{array}{l}\text { Backtesting VaR } \\
\text { dengan ARCH }\end{array}$} & \multicolumn{2}{|c|}{$\begin{array}{l}\text { Total } \\
\text { Failure }\end{array}$} & \multicolumn{2}{|c|}{ Kriteria Kupiec } & \multirow[t]{2}{*}{ Hasil } \\
\hline & $99 \%$ & $95 \%$ & $99 \%$ & $95 \%$ & \\
\hline JKSE & 145 & 154 & $\mathrm{~N}<7$ & $6<N<20$ & DITOLAK \\
\hline KLSE & 110 & 127 & $\mathrm{~N}<7$ & $6<N<20$ & DITOLAK \\
\hline STI & 149 & 162 & $\mathrm{~N}<7$ & $6<\mathrm{N}<20$ & DITOLAK \\
\hline SSE & 170 & 181 & $\mathrm{~N}<7$ & $6<N<20$ & DITOLAK \\
\hline PSEI & 97 & 110 & $\mathrm{~N}<7$ & $6<N<20$ & DITOLAK \\
\hline HANGSENG & 145 & 156 & $\mathrm{~N}<7$ & $6<\mathrm{N}<20$ & DITOLAK \\
\hline NIKKEI & 155 & 159 & $\mathrm{~N}<7$ & $6<N<20$ & DITOLAK \\
\hline KOSPI & 162 & 174 & $\mathrm{~N}<7$ & $6<\mathrm{N}<20$ & DITOLAK \\
\hline
\end{tabular}

Tabel 22.

Pengujian VaR dengan pemodelan volatilitas ARCH

Dari Tabel 22 terlihat bahwa untuk model VaR dengan tingkat kepercayaan 99\%, hipotesis 1 ditolak untuk semua indeks saham, hal ini dikarenakan Total Failure melebihi jumlah yang persyaratan Kupiec Criteria. Dikarenakan pada pemodelan VaR menggunakan tingkat kepercayaan 99\% semua indeks saham tidak memenuhi kriteria Kupiec, maka dilakukan lagi pemodelan baru dengan menggunakan tingkat kepercayaan sebesar 95\%. Hal ini dilakukan untuk mengetahui apakah dengan tingkat kepercayaan yang lebih rendah model VaR ini dapat diterima atau tidak. Seperti yang terlihat dari Tabel 22 di atas, untuk model VaR (95\%), hipotesis 2 juga ditolak untuk semua indeks saham.

\section{5}


JURNAL

MANAJEMEN

INDONESIA

Vol. 12 - No. 4

April 2013

Tabel 23.

Pengujian VaR dengan pemodelan volatilitas GARCH

Tabel 24 Pengujian VaR dengan pemodelan volatilitas EGARCH

\begin{tabular}{|l|l|l|l|l|l|}
\hline \multirow{2}{*}{$\begin{array}{l}\text { Backtesting VaR } \\
\text { dengan GARCH }\end{array}$} & \multicolumn{2}{|l|}{$\begin{array}{l}\text { Total } \\
\text { Failure }\end{array}$} & \multicolumn{2}{l}{ Hasil } \\
\cline { 2 - 5 } & $99 \%$ & $95 \%$ & $99 \%$ & $95 \%$ & \\
\hline JKSE & 144 & 154 & $\mathrm{~N}<7$ & $6<\mathrm{N}<20$ & DITOLAK \\
\hline KLSE & 91 & 110 & $\mathrm{~N}<7$ & $6<\mathrm{N}<20$ & DITOLAK \\
\hline STI & 161 & 168 & $\mathrm{~N}<7$ & $6<\mathrm{N}<20$ & DITOLAK \\
\hline SSE & 180 & 189 & $\mathrm{~N}<7$ & $6<\mathrm{N}<20$ & DITOLAK \\
\hline PSEI & 105 & 117 & $\mathrm{~N}<7$ & $6<\mathrm{N}<20$ & DITOLAK \\
\hline HANGSENG & 152 & 160 & $\mathrm{~N}<7$ & $6<\mathrm{N}<20$ & DITOLAK \\
\hline NIKKEI & 158 & 159 & $\mathrm{~N}<7$ & $6<\mathrm{N}<20$ & DITOLAK \\
\hline KOSPI & 174 & 180 & $\mathrm{~N}<7$ & $6<\mathrm{N}<20$ & DITOLAK \\
\hline
\end{tabular}

Dari Tabel 23 terlihat bahwa untuk model VaR dengan tingkat kepercayaan 99\%, hipotesis 1 ditolak untuk semua indeks saham, hal ini dikarenakan Total Failure melebihi jumlah yang persyaratan Kupiec Criteria. Dikarenakan pada pemodelan VaR menggunakan tingkat kepercayaan 99\% semua indeks saham tidak memenuhi kriteria Kupiec, maka dilakukan lagi pemodelan baru dengan menggunakan tingkat kepercayaan sebesar 95\%. Hal ini dilakukan untuk mengetahui apakah dengan tingkat kepercayaan yang lebih rendah model VaR ini dapat diterima atau tidak. Seperti yang terlihat dari Tabel 23 di atas, untuk model VaR (95\%), hipotesis 2 juga ditolak untuk semua indeks saham.

\begin{tabular}{|c|c|c|c|c|c|}
\hline \multirow{2}{*}{$\begin{array}{l}\text { Backtesting VaR } \\
\text { dengan } \\
\text { EGARCH }\end{array}$} & \multicolumn{2}{|c|}{$\begin{array}{l}\text { Total } \\
\text { Failure }\end{array}$} & \multicolumn{2}{|c|}{ Kriteria Kupiec } & \multirow[t]{2}{*}{ Hasil } \\
\hline & $99 \%$ & $95 \%$ & $99 \%$ & $95 \%$ & \\
\hline JKSE & 19 & 27 & $\mathrm{~N}<7$ & $6<\mathrm{N}<20$ & DITOLAK \\
\hline KLSE & 0 & - & $\mathrm{N}<7$ & - & DITERIMA \\
\hline STI & 0 & - & $\mathrm{N}<7$ & - & DITERIMA \\
\hline SSE & 0 & - & $\mathrm{N}<7$ & - & DITERIMA \\
\hline PSEI & 0 & - & $\mathrm{N}<7$ & - & DITERIMA \\
\hline HANGSENG & 0 & - & $\mathrm{N}<7$ & - & DITERIMA \\
\hline NIKKEI & 0 & - & $\mathrm{N}<7$ & - & DITERIMA \\
\hline KOSPI & 2 & - & $\mathrm{N}<7$ & - & DITERIMA \\
\hline
\end{tabular}

Dari Tabel 24 terlihat bahwa untuk model VaR dengan tingkat kepercayaan 99\%, hipotesis 1 diterima untuk semua indeks saham, kecuali untuk indeks saham JKSE hal ini dikarenakan Total Failure melebihi jumlah persyaratan Kupiec Criteria. Dikarenakan pada indeks saham JKSE hipotesis 1 ditolak, maka dilakukan lagi pemodelan baru dengan menggunakan tingkat kepercayaan sebesar 95\%. Hal ini dilakukan untuk mengetahui apakah dengan tingkat kepercayaan yang lebih rendah model VaR ini dapat diterima atau tidak. Seperti yang terlihat dari Tabel 24 di atas, untuk model VaR (95\%), hipotesis 2 juga ditolak untuk indeks saham JKSE. Pemodelan baru dengan tingkat kepercayaan 95\% hanya dilalukan pada indeks saham JKSE karena pada pengujian dengan tingkat kepercayaan 99\%, hipotesis 1 ditolak. Sedangkan untuk ketujuh saham lainnya hipotesis 1 diterima jadi tidak diperlukan lagi pemodelan baru dengan tingkat kepercayaan 95\%.

106 


\section{KESIMPULAN DAN SARAN}

Kesimpulan

JURNAL

Hasil pengujian Backtesting adalah sebagai berikut :

MANAJEMEN

INDONESIA

1. Untuk periode tiga tahun sebelum terjadinya krisis global tahun 2008 (2005-2007) model VaR berbasis ARCH dan GARCH dengan tingkat kepercayaan 99\% maupun 95\% tidak dapat diterima untuk semua indeks saham, yaitu pada Jakarta Composite Index (JKSE), Kuala Lumpur Composite Index (KLSE), Straits Times Index (STI), Philippines Stock Exchange index (PSEi), Hang Seng Index (HSI), Korea Composite Stock Price Index (KOSPI), Shanghai Stock Exchange (SSE), dan Nikkei 225 (N225). Hal ini dikarenakan, total failure yang terjadi di semua indeks pada tahun 2005-2007 tidak sesuai atau melewati batas Kriteria Kupiec. Sedangkan VaR berbasis EGARCH dengan tingkat kepercayaan 99\% diterima di semua indeks saham, kecuali pada indeks Jakarta Composite Index (JKSE) yang ditolak pada periode 2005-2007, Philippines Stock Exchange index (PSEi) diterima pada tingkat kepercayaan 95\% pada tahun 2006 dan ditolak pada tahun 2007 untuk tingkat kepercayaan 99\% maupun 95\% dan Korea Composite Stock Price Index (KOSPI) ditolak 99\% maupun 95\% pada periode tahun 2007.

2. Untuk periode tahun 2008 (ketika terjadi krisis) model VaR berbasis ARCH dan GARCH dengan tingkat kepercayaan 99\% maupun 95\% tidak dapat diterima untuk semua indeks saham, yaitu pada Jakarta Composite Index (JKSE), Kuala Lumpur Composite Index (KLSE), Straits Times Index (STI), Philippines Stock Exchange index (PSEi), Hang Seng Index (HSI), Korea Composite Stock Price Index (KOSPI), Shanghai Stock Exchange (SSE), dan Nikkei 225 (N225). Hal ini dikarenakan, total failure yang terjadi di semua indeks pada tahun 2008 tidak sesuai atau melewati batas Kriteria Kupiec. Sedangkan VaR berbasis EGARCH dengan tingkat kepercayaan 99\% diterima hanya pada tiga indeks saham, yaitu Kuala Lumpur Composite Index (KLSE), Shanghai Stock Exchange (SSE), dan Hang Seng Index (HSI), hal ini terjadi karena pada ketiga indeks tersebut total failure tidak melebihi kriteria Kupiec,kelima indeks lainnya juga ditolak pada tingkat kepercayaan 95\%.

3. Untuk periode empat tahun setelah terjadinya krisis global tahun 2008 (2009-2012) model VaR berbasis ARCH dan GARCH dengan tingkat kepercayaan 99\% maupun 95\% tidak dapat diterima untuk semua indeks saham, yaitu pada Jakarta Composite Index (JKSE), Kuala Lumpur Composite Index (KLSE), Straits Times Index (STI), Philippines Stock Exchange index (PSEi), Hang Seng Index (HSI), Korea Composite Stock Price Index (KOSPI), Shanghai Stock Exchange (SSE), dan Nikkei 225 (N225). Hal ini dikarenakan, total failure yang terjadi di semua indeks pada tahun 2009-2012 tidak sesuai atau melewati batas Kriteria Kupiec. Sedangkan VaR berbasis EGARCH dengan tingkat kepercayaan 99\% diterima di semua indeks saham, kecuali pada indeks Jakarta Composite Index (JKSE) yang ditolak pada periode 2009-2012, Korea Composite Stock Price Index (KOSPI) ditolak pada tahun 2009 dan 2011, namun setelah dilakukan lagi pemodelan pada Korea Composite Stock Price Index (KOSPI) dengan tingkat kepercayaan 95\% model diterima untuk periode 2009 dan 2011.

\section{Saran}

\section{Bagi Praktisi}

Bagi investor, model VaR semi-parametric dengan menggunakan pemodelan volatilitas ARCH, GARCH dan EGACRH yang dinyatakan valid setelah diuji dengan backtesting, bisa dijadikan sebagai bahan masukan/ pertimbangan bagi investor dalam memahami risiko apabila berinvestasi dalam saham seperti pengukuran potensi kerugian, alokasi penempatan modal sehingga dapat mengetahui seberapa besar risiko yang dihadapi di masa yang akan datang.

\section{Bagi Akademisi}

Bagi akademisi, dapat dijadikan masukan dan pertimbangan untuk penelitian selanjutnya. Dalam penelitian ini, pengujian model VaR dengan menggunakan volatilitas saham ARCH 
JURNAL

MANAJEMEN

INDONESIA

Vol. 12 - No. 4

April 2013 dan GARCH dinyatakan tidak valid, namun dengan model EGARCH memberikan hasil yang lebih baik. Di penelitian selanjutnya dapat dipertimbangkan untuk menggunakan ragam turunan $\mathrm{GARCH}$ yang lain seperti TARCH dan IGARCH yang mampu menangkap leverage effect seperti halnya model EGARCH.

\section{DAFTAR PUSTAKA}

Alfranseder, Emanuel. (2009). Volatility and Contagion effects originating from the financial sector: An analysis of economic sectors in two different stock market downturns. Lund University School of Economics and Management Master Essay.

Barone-Adesi G, F Bourgoin, Giannopoulos, K. (1998). Don't Look Back, Risk, 11, August, pp100-104.

Barone-Adesi, G. F Bourgoin, Giannopoulos, K. (2000). Non-parametric VaR techniques. Myths and Realities, unpublished manuscript.

Bodie, Zvi, Kane, Alex, Marcus, Alan J. (2010). Essentials of Invesment, New York: The Mc Graw- Hill.

Bodie, Zvi, Kane, Alex, Marcus, Alan J. (2011). Investments and Portfolio Management Global Edition, New York: The Mc.Graw-Hill.

Bollerslev, Tim. (1986). Generalized Autoregressive Conditional Heteroskedsticity. Journal of Econometrics, 31, 307-327.

Cabedo, Moya. (2003). Estimating Oil Price Value at Risk Using the Historical Simulation Approach. Journal of Economy, v25, 239-253.

Chang, Su (2010). Application of EGARCH Model to Estimate Financial Volatility of Daily Returns: The empirical case of China. University of Gothenburg School of Business, Economics and Law Master Thesis.

Choudhry, Michael. (2006). Risk Management, New York: The Mc Graw-Hill.

Choudhry, Moorad. (2006). An Introduction to Value at Risk, London: John Wiley\&Sons Ltd.

Christoffersen \& Pelletier. (2004). Backtesting Value at Risk: A Duration-Based Approach. Journal of Financial Econometrics, Vol. 2, No.1, pp. 84-108.

Cruz, G. Marcelo. (2002). Modelling, Measuring and Hedging Operational Risk, London: John Wiley and Sons.

Dany, Ng Cheong Vee, Gonpot, Preethe Nunkho, Sookia, Noor. (2012). Assessing the performance of generalized autoregressive conditional heterokedasticity-based value at risk model: a case of frontier markets. Journal of risk model Validation, Vol.6, No. 4.

Enders, W. (1995) Applied econometric time series $1^{\text {st }}$ edition, Canada: John Willey \& Sons, Inc. Fahmi, Irham. (2010). Manajemen risiko teori, kasus, dan solusi, Jakarta: ALFABETA.

Farid, D., Meybodi, A.R., \& Mirfakhraddiny, S.H. (2010). Investment risk management in Tehran Stock Exchange (TSE) using technique of Monte Carlo Simulation (MCS). Vol. 17 No. 2, 2010 pp. 265-278.

Greene, William H. (2000). Econometric Analysis $4^{\text {th }}$ Edition, New Jersey: Prentice Hall International Inc.

Hanafi, Mahmud, M. (2009). Manajemen Risiko, (Cetakan 2), Yogyakarta: Unit Penerbit dan Percetakan Sekolah Tinggi Ilmu Manajemen YKPN.

Hull, John. (2006). Option, Futures, and Other Derivatives $6^{\text {th }}$ Edition, New Jersey: Pearson Prantice Hall

Jogiyanto, Hartono. (2007). Teori Portofolio dan Analisis Investasi, Yogyakarta: BPFE.

Jorion, Philippe. (2007). Value at Risk: The New Benchmark for Managing Financial Risk, Singapore: Mc Graw-Hill.

Juanda B., Junaidi. (2012). Ekonometrika dan Deret Waktu, Bogor: IPB Press. 
Kahar, Yuskar. (2009). Perhitungan Value at Risk pada Institusi Perbankan berdasarkan Metode Variance Covariance. Vol. 8. No. 2, 2009: 160-181.

Kountor, Rony. (2008). Mudah Memahami Manajemen Risiko Perusahaan, Jakarta: PPM.

Kupiec, Paul. (1995). Techniques for Verifying the Accuracy of Risk Measurement Models. Journal of Derivatives 2, 73-84.

Liu, Yang. (2012). Risk forecasting and portofolio with GARCH, SKEWED T distribution and multiple time scales. The Florida State University College of Arts and Sciences Dissertation.

Mc.Donald, Robert L. (2006). Derivatives Markets $2^{\text {nd }}$ Edition, Boston: Person Education, Inc. Nippola, Olli. (2009). Backtesting Value at Risk Model, Helsinki Economics.

Peterscu, Mirea. (2007). A study on the accuracy of reduced-form VaR methods. School of Business George Washington University Dissertation.

Piroozfar, Ghashang. (2009). Forecasting Value at Risk with Historical and Filtered Historical Simulation Methods. Department of Mathematics Uppsala University Master Thesis

Rejda, George. (2008). Principles of risk management and insurance, United State of America: Pearson Addsion Wesley.

Sari, Dyah W., Ajija, Shochrul R., Stianto, Rahmat H., Primanti, Martha R. (2011). Cara Cerdas Menguasai Eviews, Jakarta: Salemba Empat.

Sartono, Setiawan. (2006). VaR Portofolio Optimal: Perbandingan Antara Metode Dan Mean Absolute Deviation. Jurnal Siasat Bisnis, Vol. 11, No.1.

Sheedy, Elizabeth (2008). Why VaR models fail and what can be done. MAFC Research Papers no.34, October.

Sheedy, Elizabeth (2009). Can Research Modeling Work?. MAFC Research Papers no.35, June. Sjo, Bo (2011). Estimation and Testing for ARCH and GARCH. International Journal of Finance.

Sollis, Robert. (2009). Value at risk: a critical overview. Vol. 17 No. 4 pp. 398-414.

Sugiyono. (2011). Metode Penelitian Kuantitatif, Kualitatif dan R\&D, Bandung: ALFABETA.

Sulastri. (2013). Penentuan Harga Opsi Barrier Mengguanakn Metode Trinominal KmradRitchken Dengan Volatilitas GARCH. Tesis Master Pada Universitas Padjajaran. Bandung: tidak diterbitkan.

Sunaryo, T. (2007). Manajemen Risiko Finansial, Jakarta: Salemba Empat.

Vogelvang, Ben. (2005). Econometrics Theory and Applications with EViews, London: Pearson Addison Wesley.

Wong, Michael, et. al. (2003). Market risk management of banks:Implications from the accuracy of Value at risk forecasts. Journal of Forecasting.

Wu, Po-Cheng, et. al. (2012). Evaluation of Multi-asset Value at risk: Evidence from Taiwan. Global Journal of Business Research Vol. 6, No. 4

Yakov, Ben-Haim. (2005). Value-at-risk with info-gap uncertainty. Journal of Risk Finance, Vol. 6 Iss: 5, pp.388- 403.

Zikmund, William G., Bubin, B.J., \& Carr, Jon C. (2010). Business Research Methods, Eighth Edition. South-Western: Cengage Learning.
JURNAL

MANAJEMEN

INDONESIA

Vol. 12 - No. 4

April 2013

\section{9}

